\title{
EWSR1/SP3 Fusion Protein
}

National Cancer Institute

\section{Source}

National Cancer Institute. EWSR1/SP3 Fusion Protein. NCI Thesaurus. Code C99511.

A fusion protein encoded by the EWSR1/SP3 fusion gene. This protein is comprised of the transactivation domain of the RNA-binding protein EWS fused to a $\mathrm{C} 2 \mathrm{H} 2$ zinc finger DNA binding domain of the transcription factor Sp3 protein. 